\title{
Konsep Preferensi Dalam Alquran: Studi Analisis Kata Khair Pada Ayat-Ayat Alquran
}

\author{
Muhammad Reza Fadil \\ IAIN Langsa, Provinsi Aceh-Indonesia \\ mrezafadil@iainlangsa.ac.id
}

DOI: http://dx.doi.org/10.29240/alquds.v3i2.926

Submitted: 2019-07-02 | Revised: 2019-10-07 | Accepted: 2019-11-06

\begin{abstract}
Preference is the tendency to choose or determine something that is considered better by leaving others. This concept is found in the style of the Quran language, which is located in the verses that have the word (خير) in it. However, not all words (خير) contain preferences, because the word (خير) in the Quran has many meanings. But, if this word (خير) combines with other words to form the phrase (خير) خلكم خير) $\left.{ }^{5}\right)$ then it can be understood that the verse contains the concept of preference. This article will prove this hypothesis by analyzing the word (خير) especially when combined with other words to form the phrase (نلكم خير لكم). This research was conducted with a qualitative method of library research type by approaching aspects of assessment through semantic studies. This study aims to prove the existence of the concept of preference in the Quran and find out what is the function of the phrase language style so that it is mentioned repeatedly in the Quran. As a result of the findings, it was found that of the many meanings of the word (خير) in the Quran, however, if the word (خير) forms a phrase (ذلكم خير لكم) then it is true and proven that the verse contains the concept of Allah's preference. While the function of the phrase style of language is to emphasize or affirm the command contained in the verse, the suggestion to humans to make choices about what God commands in that verse, and as a good method of communication
\end{abstract}

Keywords: preference, khair, musytarak, mutarâdif

\begin{abstract}
Abstrak. Preferensi merupakan kecenderungan untuk memilih atau menentukan sesuatu yang dianggap lebih baik dengan meninggalkan yang lainnya. Konsep seperti ini ditemukan di dalam gaya bahasa Alquran, yakni yang terletak pada ayat-ayat yang terdapat kata (خير) di dalamnya. Namun, tidak semua kata (خير) mengandung preferensi, sebab kata (خير) di dalam Alquran memiliki banyak makna. Tapi, jika kata (خير) ini bergabung dengan kata lain membentuk frasa (نكم خير لكم) maka dapat dipahami bahwa ayat itu mengandung konsep preferensi. Artikel ini akan membuktikan hipotesis ini dengan menganalisis kata (خير) terlebih ketika tergabung dengan kata lain membentuk frasa (نلكم خير لكم) . Penelitian ini dilakukan dengan metode kualitatif jenis studi kepustakaan (library research) dengan mendekati aspek pengkajian melalui studi semantik.
\end{abstract}


Penelitian ini bertujuan untuk membuktikan keberadaan konsep preferensi di dalam Alquran dan mencari tahu apa hikmah dari gaya bahasa frasa (نلكم خير لكم) sehingga penyebutannya berulang-ulang di dalam Alquran. Sebagai hasil temuan, maka didapati bahwa dari sekian banyak makna-makna kata (خير) di dalam Alquran, namun jika kata (خير) tersebut membentuk frasa (ذلكم خير لكم) maka benar dan terbukti adanya bahwa ayat tersebut mengandung konsep preferensi Allah. Sementara faedah dari gaya bahasa frasa tersebut adalah memberi penekanan atau penegasan pada perintah yang terkandung di dalam ayat, sugesti kepada manusia untuk menjatuhkan pilihan kepada apa yang Allah perintahkan di dalam ayat itu, dan sebagai metode komunikasi yang baik.

Kata Kunci: preferensi, khair, musytarak, mutaradif

\section{Pendahuluan}

Manusia mampu menghasilkan ide-ide dari alam pikirannya guna menentukan tindakannya. Jikalau seseorang mampu berpikir dengan baik, maka ia dapat menjalani kehidupan dengan baik pula. Sebab, akal yang baik akan tunduk dan patuh kepada kehendak Yang Menciptakannya ${ }^{1}$. Namun, tidak setiap manusia mampu menggunakan karunia akal itu dengan sebaik-baiknya karena Allah juga menciptakan hawa nafsu di dalam diri manusia yang dapat mempengaruhi akal. Itu mengapa Allah Swt. menurunkan Alquran sebagai pedoman kehidupan melalui manusia terpilih yang ditugaskan untuk menyebarkan dan menjelaskannya. Sehingga tidak ada kesempatan bagi manusia yang lalai untuk berdalih setelah diutusnya para rasul dengan membawa peringatan.

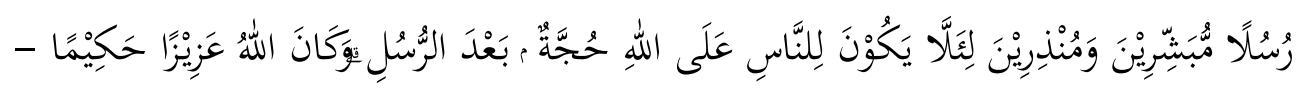

Rasul-rasul itu adalah sebagai pembawa berita gembira dan pemberi peringatan, agar tidak ada alasan bagi manusia untuk membantab Allab setelab rasul-rasul itu diutus. Allah Mahaperkasa, Mahabijaksana. (QS. An-Nisâ: 165) ${ }^{2}$

Kehidupan manusia tak luput dari pilihan-pilihan. Kondisi seperti ini membuat manusia membutuhkan perangkat pada dirinya untuk dapat mengambil keputusan ketika dihadapkan pada pilihan-pilihan itu. Namun, jiwa yang mampu berpikir itu sendiri merupakan satu langkah awal bagi manusia untuk menentukan pilihan. Sebab, jiwa bergantung pada pilihan manusia. Apakah manusia hendak mensucikannya atau justru mengotorinya. Alquran

${ }^{1}$ Muhammad Fethullah Gulen, Islam, Penerjemah Fauzi A. Bahreisy (Jakarta: Republika Penerbit, 2011) h. 206

${ }^{2}$ Seluruh lafal Alquran berikut terjemahannya di dalam artikel ini diambil dari web Quran Kemenag; https://quran.kemenag.go.id// 
menjelaskan, jika ia memilih untuk mensucikannya maka ia tergolong orang yang beruntung. Sebaliknya, jika ia memilih untuk mengotorinya maka ia tergolong orang yang merugi.

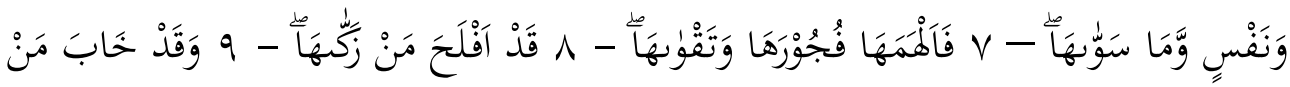

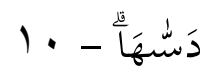

Demi jiwa serta penyempurnaan (ciptaan)nya, maka Dia mengilhamkan kepadanya (jalan) kejahatan dan ketakwaannya, sungguh beruntung orang yang menyucikannya (jiwa itu), dan sungguh rugi orang yang mengotorinya. (Qs. Asy-Syams: 7-10)

Dalam memilih sesuatu, manusia melandaskan pilihannya itu dengan keinginan. Sementara keinginan dipengaruhi oleh pandangannya terhadap pilihan-pilihan itu sehingga melahirkan rasa suka atau tidak suka, mau atau tidak mau. Contohnya, seseorang dihadapkan pada sebuah pilihan antara susu dan khamar. Pada saat itu ia berpandangan bahwa susu adalah sesuatu yang lebih baik dibandingkan khamar karena mengandung nutrisi yang baik bagi tubuh. Sementara di sisi lainnya ia menganggap khamar adalah suatu keburukan yang dapat mendatangkan penyakit. Kemudian keinginannya berperan. Jikalau ia ingin kebaikan pada dirinya, ia akan memilih susu. Jika tidak, maka ia akan memilih khamar.

Terkait dengan hal ini Allah juga memiliki kehendak untuk memilih sesuai dengan keinginan-Nya. Sehingga antara keinginan manusia dan keinginan Allah dalam memilih sesuatu tak selamanya sama. Apa yang dianggap manusia baik, belum tentu baik pula di hadapan Allah. Seperti yang terjadi pada masa nabi atas orang-orang yang tidak menyukai peperangan.

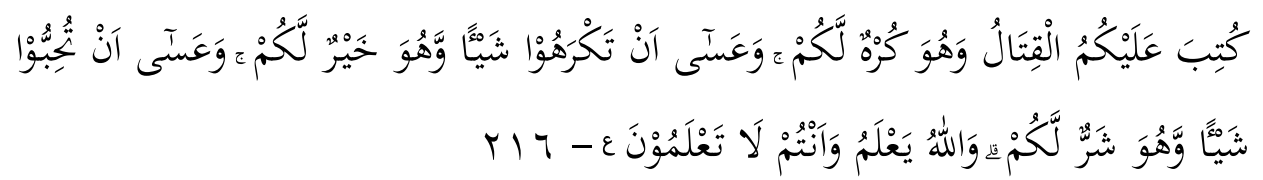

Diwajibkan atas kamu berperang, padahal itu tidak menyenangkan bagimu. Tetapi boleh jadi kamu tidak menyenangi sesuatu, padahal itu baik bagimu, dan boleh jadi kamu menyukai sesuatu, padahal itu tidak baik bagimu. Allah mengetabui, sedang kamu tidak mengetahui. (Qs. Al-Baqarah: 216)

Kecenderungan Allah untuk memilih sesuatu daripada yang lainnya dapat ditemukan pada ayat-ayat yang terdapat kata (خير) di dalamnya. Contohnya seperti pada Qs. Al-Baqarah ayat 61, 


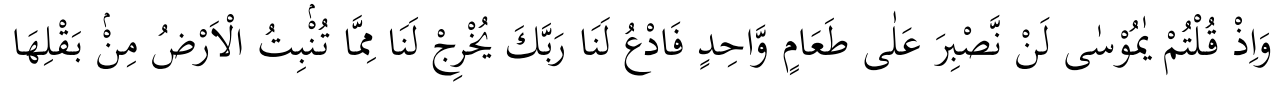

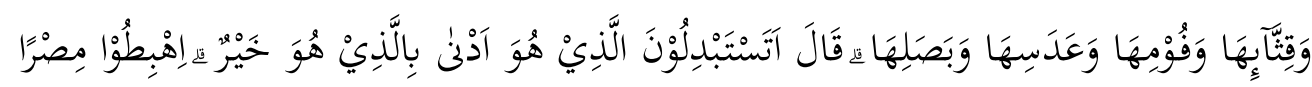

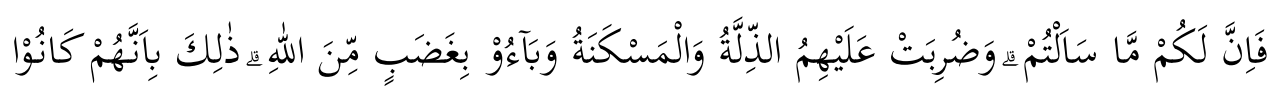

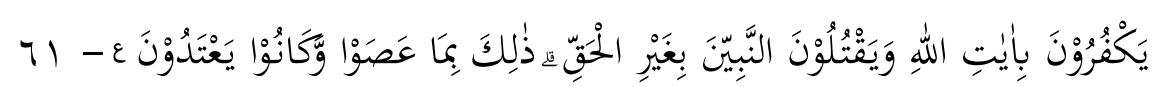

Dan (ingatlab), ketika kamu berkata, "Wahai Musa! Kami tidak tahan banya (makan) dengan satu macam makanan saja, maka mohonkanlah kepada Tubanmu untuk kami, agar Dia memberi kami apa yang ditumbubkean bumi, seperti: sayur-mayur, mentimun, bawang putih, kacang adas dan bawang merah." Dia (Musa) menjawab, "Apakah kamu meminta sesuatu yang buruk sebagai ganti dari sesuatu yang baik? Pergilah ke suatu kota, pasti kamu akan memperoleh apa yang kamu minta." Kemudian mereka ditimpa kenistaan dan kemiskinan, dan mereka (kembali) mendapat kemurkaan dari Allah. Hal itu (terjadi) karena mereka mengingkari ayat-ayat Allab dan membunuh para nabi tanpa bake (alasan yang benar). Yang demikian itu karena mereka durbaka dan melampaui batas.

Sayur mayur, ketimun, bawang putih, kacang adas, dan bawang merah sebenarnya adalah bahan makanan yang pernah dinikmati oleh Bani Israil ketika masih berada di Mesir. Itu berarti jenis-jenis makanan yang mereka pinta itu sebenarnya halal bagi mereka. Hanya saja apa yang mereka minta kepada nabinya itu adalah sesuatu yang lebih rendah di sisi Allah dan Rasul-Nya. Allah lebih memilih manna dan salwa untuk mereka sebagai bahan makanan selama dalam perjalanan menuju Hebron dibandingkan yang lainnya. ${ }^{3}$

Kecenderungan Allah dalam memilih sesuatu daripada yang lainnya ini penulis sebut dengan istilah preferensi. Pada QS. Al-Baqarah ayat 61 ini misalnya, preferensi Allah di dalamnya terletak pada kecenderungan-Nya terhadap manna dan salwa. Sayur mayur, ketimun, bawang putih, kacang adas, dan bawang merah adalah sesuatu yang baik. Di sisi lain manna dan salwa adalah sesuatu yang baik pula. Namun, pada saat kondisi dalam perjalanan ketika itu Allah lebih memilih manna dan salwa untuk Bani Israil.

Contoh lainnya seperti QS. Al-Kahfi ayat 46

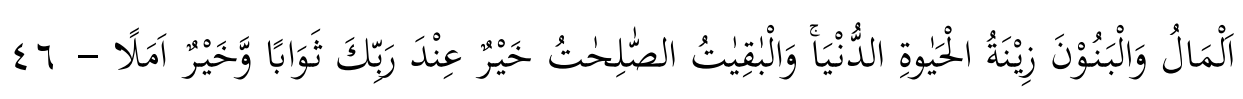

Harta dan anak-anak adalab perbiasan kebidupan dunia tetapi amal kebajikan yang terusmenerus adalah lebih baik pahalanya di sisi Tubanmu serta lebih baik untuk menjadi barapan.

\footnotetext{
${ }^{3}$ M. Quraish Shihab, Tafsir al-Misbah. (Jakarta : Lentera hati, 2000) hal. 210
} 
Antara perhiasan kehidupan dunia, yakni harta dan anak-anak, dengan amalan-amalan yang kekal lagi saleh, Allah menyatakan pilihan bahwa amalanamalan yang kekal lagi saleh sebagai sesuatu yang lebih baik dibandingkan harta dan anak-anak itu.

Contoh lainnya juga terdapat pada QS. Adh-Dhuhâ ayat 4

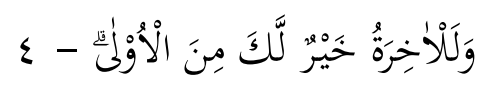

Dan sungguh, yang kemudian itu lebih baik bagimu dari yang permulaan.

Antara kehidupan dunia dengan kehidupan akhirat. Sudah pasti, sesuai dengan ayat ini, Allah lebih menetapkan pilihan kepada kehidupan akhirat lebih baik daripada kehidupan dunia.

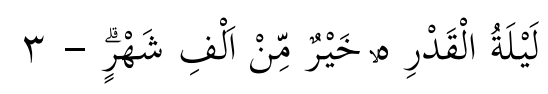

Malam kemuliaan itu lebih baik daripada seribu bulan. (QS. Al-Qadr ayat 3)

Dibandingkan dengan bulan-bulan biasa yang berjumlah seribu, Allah menetapkan laylatul qadr sebagai sesuatu yang lebih baik daripada bulan-bulan yang berjumlah seribu itu.

Namun, persoalan berikutnya adalah tidak semua ayat-ayat yang mengandung kata (خير) menunjukkan adanya preferensi. Sebab, kata (خير) di dalam Alquran tidak hanya memiliki satu makna melainkan banyak makna (musytarak). Dengan demikian, tulisan ini akan mengkaji dan meneliti dalam konteks dan makna apa saja kata khair digunakan di dalam Alquran, mengapa kata khair jika bertemu dengan beberapa kata lain membentuk frasa dzâlikum khairul lakum berulang-ulang penyebutannya di dalam Alquran dan dalam konteks apa frasa itu berbicara. Berangkat dari beberapa pertanyaan tersebut maka penelitian ini akan ditempuh dengan metode penelitian kualitatif jenis penelitian kepustakaan (library research) dan didekati dengan pendekatan semantik atau studi analisis kata.

Beberapa penelitian sebelumnya seperti Ahmad Faiz dalam Analisis Kata Khair, Hasan, Thayib dalam Alquran Berdasarkan Tafsir Ibnu Katsir, Jalalain, Departemen Agama dan Baghawy, membahas kata khair dalam Alquran merujuk pada penafsiran-penafsiran tertentu kemudian mencari perbandingan makna dengan kata hasan dan thayib. ${ }^{4}$ Enoh dalam Konsep Baik (Kebaikan) dan Buruk

4 Ahmad Faiz. Analisis Perbandingan Kata Khair, Hasan, dan Thayyib dalam Al-Quran Berdasarkan Tafsir Ibnu Katsir, Jalalain, Departemen Agama dan Baghawy. (Skripsi, Jurusan Sastra Arab, Fakultas Sastra, Universitas Negeri Malang, 2016). 
(Keburukan) dalam Alquran, menjelaskan bagaimana rumusan konsep baik dan buruk berdasarkan telaah istilah-istilah Alquran ${ }^{5}$. Yulia Rahmi dalam Makna Khair dalam Alquran menggambarkan seputar kata khair di dalam Alquran secara sederhana tanpa analisis lebih dalam lagi. ${ }^{6}$ Penelitian-penelitan tersebut tidak satupun menyinggung atau mengkaitkan analisis kata kbair dengan konsep preferensi di dalam Alquran. Sementara tulisan ini akan menganalisis kata khair di dalam Alquran secara komprehensif dan memberi perhatian lebih pada ayat yang memiliki frasa dzâlikum khairul lakum, sehingga tulisan ini bertujuan untuk membuktikan keberadaan konsep preferensi di dalam Alquran dan mencari atau apa hikmah dari berulang-ulangnya frasa dzâlikum khairul lakum dalam Alquran ditinjau dari sisi gaya bahasa.

\section{Definisi Preferensi}

Preferensi merupakan kata serapan dalam Bahasa Indonesia yang berasal dari Bahasa Inggris, yaitu preference. Di dalam kamus Bahasa Inggris, preference memiliki beberapa arti yaitu pilihan, lebih suka daripada, atau lebih baik daripada. ${ }^{7}$ Di dalam Cambridge Dictionary disebutkan bahwa preference adalah when you like something or someone more than another person or thing ${ }^{8}$, yakni 'ketika kamu menyukai sesuatu atau seseorang lebih daripada orang atau sesuatu lainnya'.

Di dalam Kamus Besar Bahasa Indonesia (KBBI) preferensi merupakan hak untuk didahulukan dan diutamakan daripada yang lain, prioritas, pilihan, atau kecenderungan ${ }^{9}$. Sementara di dalam kosa kata Arab, esensi makna dari kata preferensi ini bisa dimaknai dengan istilah tafdhîl. Jadi, preferensi adalah kecenderungan untuk memilih atau menentukan sesuatu yang dianggap lebih baik daripada yang lainnya.

Pada penerapannya dalam beberapa disiplin ilmu, istilah preferensi ini mengalami penyesuaian makna. Namun, makna-makna pada masing-masing disiplin ilmu itu tidak terlepas pula dari pengertian dasarnya. Misalnya pada bidang finance terdapat istilah saham preferen untuk menunjukkan kelas saham yang paling tinggi dan diprioritaskan. Di bidang psikologi preferensi dapat

\footnotetext{
${ }^{5}$ Enoh, "Konsep Baik (Kebaikan) dan Buruk (Keburukan) dalam Alquran,” Mimbar Jurnal Ilmu Sosial dan Pembangunan Vol. 23 No. 1 Tahun 2007. Lihat https://ejournal.unisba.ac.id/index.php/mimbar/article/view/232

${ }^{6}$ Yulia Rahmi, Makna Khair dalam Alquran, (Skripsi, Fakultas Ushuluddin dan Pemikiran Islam UIN Sunan Kalijaga Yogyakarta, 2014) 443

${ }^{7}$ John M. Echols dan Hassan Shadily, Kamus Inggris-Indonesia, (Jakarta: Gramedia, 2003) h.

${ }^{8}$ Cambridge University Team, Cambridge Advanced Learner's Dictionary, (Singapore: Green Giant Press, 2008) h. 1116

${ }^{9}$ Tim Pusat Bahasa, Kamus Besar Bahasa Indonesia, Jakarta: Gramedia Pustaka Utama, 2008) h. 1100
} 
dipahami sebagai sikap individu terhadap satu set objek. Sementara di bidang genetika terdapat istilah preferensi seksual untuk memaknai orientasi seksual seseorang.

\section{Analisis Kata Khair Dalam Alquran}

Di dalam Alquran terdapat kata-kata yang tidak hanya memiliki satu makna melainkan banyak makna. Contohnya kata (قروء) pada QS. Al-Baqarah ayat 228 ;

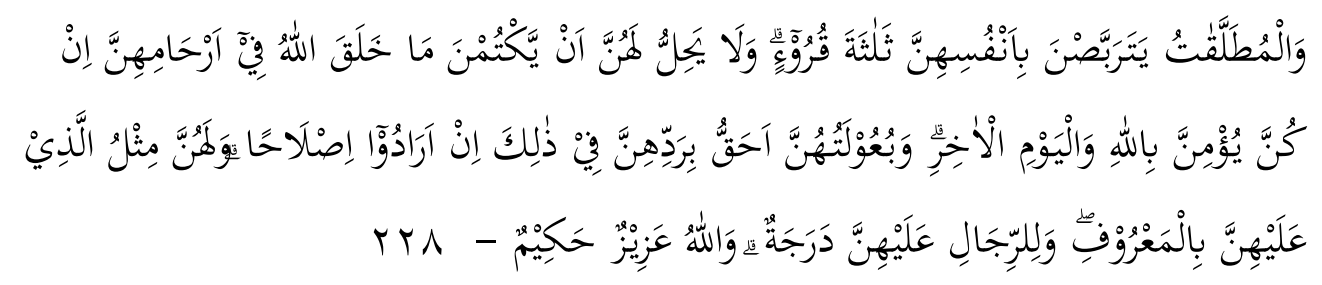

Kata (قروء) pada ayat ini memiliki dua makna yang saling berbeda. Pertama, dapat diartikan haid. Kedua, dapat diartikan bersuci. Kata-kata seperti ini di dalam 'Ulùm Alquran disebut dengan istilah musytarâk. ${ }^{10}$

Sebaliknya, ada pula beberapa kata di dalam Alquran memiliki makna yang seolah-olah sama. Contohnya kata al-khauf (الخوف) dan kata al-khasyyah yang secara sepintas sama-sama memiliki arti kata 'takut'. Namun sebenarnya, makna kata al-khasyyah lebih tinggi daripada makna kata al-khauf. Jadi, arti al-khasyyah adalah totalitas rasa takut atau rasa takut yang timbul karena agungnya pihak yang ditakuti meskipun pihak yang mengalami rasa takut itu adalah seorang yang kuat. Adapun kata-kata seperti ini disebut dengan istilah mutarâdif..$^{11}$

Terkait dengan hal ini, kata (خير) di dalam Alquran merupakan sebuah kata yang tergolong musytarâk dan mutarâdif. Sebab, kata ini tidak hanya memiliki satu makna melainkan banyak makna (musytarâk) dan juga memiliki padananpadanan kata lain yang seolah-olah mempunyai makna yang sama (mutarâdif).

${ }^{10}$ Jalaluddin Abdurrahman al-Suyuthi, al-Itqân fî Ulùm Alquran, (Beirut: al-Maktabah al'Ashriyyah, 1988) juz 3, hal. 52

${ }^{11}$ Manna' Khalil Al-Qattan, Mababits fi Ulum al-Qur'an, (Mansyurat al-Asr al-Haidis, 1973) 


\section{Kata (خير) Tergolong Musytarak}

Kata (خير) di dalam Alquran bukan hanya memiliki satu makna melainkan banyak makna. Oleh karenanya ia tergolong kata-kata yang musytarâk. Berikut ini akan dicantumkan aneka ragam makna kata (خير) di dalam Alquran: Bermakna 'paling' menunjukkan kesempurnaan Allah

Ciri khasnya adalah ia selalu dalam keadaan marfu' karena berkedudukan sebagai mubtada'. Diterjemahkan dalam Bahasa Indonesia menjadi sebaik-baik atau paling baik. Contohnya sebaik-baik Penolong (وهوخير الناصرين) , وهوير), sebaik-baik Hakim (وهو خير الحاكمين), Pemberi keputusan yang paling baik (وهوخير الفاصلين), dan lain sebagainya.

Adapun ayat-ayat yang bertajuk seperti ini yakni terdapat pada Qs. AlImrân ayat 54 dan 150, QS. Al-An'âm ayat 57, QS. Al-A'râf 87, QS. Yûsuf ayat 64, QS. Al-Kahfi ayat 44, QS. Al-Anbiyâ ayat 89, QS. Al-Haj ayat 58, QS. AlMukminûn ayat 29, 72, dan 109, dan QS. Saba' ayat 39.

\section{Bermakna 'paling' menunjukkan keutamaan makbluk.}

Jenis kedua ini hampir sama dengan sebelumnya hanya saja diperuntukkan untuk mensifati makhluk. Makhluk yang dimaksud disini adalah seorang hamba, seperti QS. Yûsuf ayat 59, QS. Al-Qashash ayat 26, dan Qs. AlBayyinah ayat 7, atau sebuah tempat seperti pada QS. Al-Furqân ayat 24.

\section{Bermakna harta}

Biasanya untuk kata yang bermakna harta di dalam Alquran menggunakan kata (مال) atau (أموال). Namun, terdapat tiga ayat di dalam Alquran yang juga bermakna harta tapi tidak menggunakan kata (مال) atau (مال) (الموال) melainkan menggunakan kata (الخير). 80, QS. Shad ayat 32, QS. Al Ma'ârij ayat 21, dan QS. Al-Adiyat ayat 8.

Harta sejatinya memiliki dua sisi, yakni sisi positif sebagai nikmat dan sarana ibadah atau sisi negatif sebagai ujian dan sarana maksiat. Harta dengan menggunakan kata (مال) atau (الموال) mewakili dua sisi itu. Terkadang ia bersifat positif seperti pada ayat berikut,

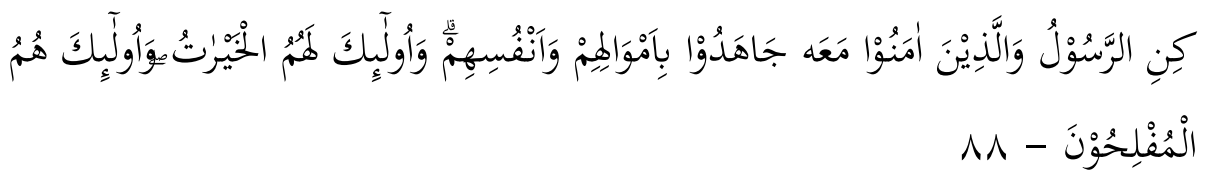

${ }^{12}$ Jalaluddin Abdurrahman Al-Suyuthi dan Jalaluddin al-Mahalli, Tafsîr al-Jalâlain, (Beirut: Dâr al-Ma'rifah) h. 818 
Tetapi Rasul dan orang-orang yang beriman bersama dia, (mereka) berjihad dengan harta dan jiwa. Mereka itu memperoleh kebaikan. Mereka itulah orang-orang yang beruntung. (QS. At-Taubah ayat 88) ujian

Terkadang pula digunakan dalam pemaknaan yang negatif, yakni sebagai

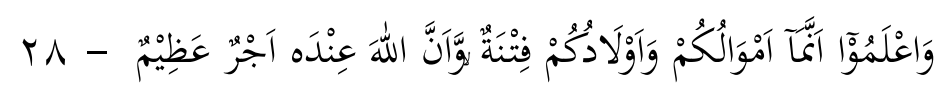

Dan ketabuilah bahwa hartamu dan anak-anakmu itu hanyalah sebagai cobaan dan sesunggubnya di sisi Allah ada pabala yang besar. (QS. Al-Anfal ayat 28)

Sementara kata (خير) dengan makna harta pada QS. Al Baqarah ayat 80, QS. Shad ayat 32, QS. Al Ma'ârij ayat 21, dan QS. Al-Adiyat ayat 8 seluruhnya mengarah pada sisi negatif, yakni sebagai sesuatu yang melalaikan. Ibnu Zaid menjelaskan hal ini dengan menyatakan bahwa kata (خير) pada ayat-ayat tersebut bertujuan untuk menjelaskan sebaliknya. Pada ayat-ayat tersebut harta ditampilkan seolah-olah suatu kebaikan (خير) bagi orang-orang yang lalai. Padahal boleh jadi ia adalah keburukan yang menyesatkan. ${ }^{13}$

Bermakna sifat

Kata (خير) di dalam beberapa ayat digunakan untuk mensifati suatu perbuatan atau amal. Kata (خير) di dalam ayat-ayat tersebut diterjemahkan di dalam Bahasa Indonesia menjadi baik, kebaikan, atau kebajikan. Ayat-ayat yang dimaksud yakni QS. Al-Baqarah ayat 184, QS. Al-Imrân ayat 115, QS. AlMaidah ayat 48, QS. Al Hâj ayat 77, QS. Qaf ayat 25, QS. Al-Qalam ayat 12, dan QS. Al-Zalzalah ayat 7. Qs. An-Nisâ ayat 19 dan 149, Qs. At-Taubah ayat 61, Qs. Hûd ayat 31 dan 84, Qs. Al-Isrâ ayat 11, Qs. Haj ayat 36, dan Qs. Fushshilat ayat 49.

\section{Bermakna Perbandingan}

Ada juga kata (خير) yang bermakna lebih baik namun penggunaannya dalam konteks membandingkan dan kata itu masuk pada dialog makhluk yang diceritakan di dalam Alquran. Contohnya seperti Qs. Shâd ayat 76,

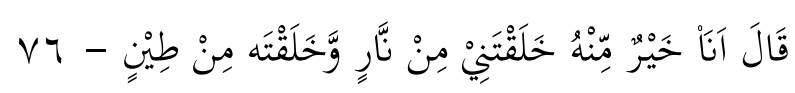

(Iblis) berkata, "Aku lebih baik daripadanya, karena Engkau ciptakan aku dari api, sedangkan dia Engkau ciptakan dari tanah." (Qs. Shâd ayat 76)

13 Abi Abdillah Muhammad bin Ahmad al-Anshâri al-Qurthubi, al-Jâmi' li Abkâm alQurân, Juz. 19-20 h. 162 
Beberapa ayat lain yang konteksnya sama seperti ayat ini yakni Qs. AzZukhruf ayat 52, Qs. Yûsuf ayat 39, Qs. Al-Kahfi ayat 81, Qs. An-Naml ayat 89, Qs. Al-Qomar ayat 32, dan Qs. Al-Ma'ârij ayat 41.

\section{Kata (خير) Tergolong Mutarâdif}

Kata (خير) tergolong mutarâdif oleh sebab ia seolah-olah memiliki padanan kata lain atau sinonim di dalam Alquran. Secara sepintas memang semua kata-kata itu dapat diartikan sama, yaitu 'kebaikan'. Namun, jika ditelusuri lebih dalam nantinya setiap kata memiliki makna ciri khas yang membedakan antara yang satu dengan yang lainnya. Adapun padanan-padanan kata yang dimaksud adalah:

Thayyibun (طيب)

Tidak seperti kata (خير), kata ini di dalam Alquran memiliki bentuk yang lengkap, yaitu terdapat dalam bentuk mufrad mudzakkar (طيب), mufrad muannats (طيبة), jamak mudzakkar sâlim (الطيبون); hanya terdapat satu ayat di dalam Alquran yakni QS. An-Nûr ayat 26, dan jamak muannats sâlim (اطيبات).

Husnun (حسن)

Kata ini bentuk-bentuknya lebih beragam lagi di dalam Alquran. Terkadang ia bermakna orang dengan bentuk isim fâ'il dari wazan (أحسن), yakni dalam bentuk jamak (محسنين). Untuk bermakna 'kebaikan' bentuknya sangat beragam, yakni (حسن, حسنى, حسنة). Ada pula yang bermakna tafdhîl (أحسن) dan kata kerja (أحسنوا).

Birrun (بر)

Kata ini dapat pula diartikan dengan 'kebaikan'. Namun, kebaikan yang dimaksud lebih ke arah 'kebaktian' atau 'berbakti'. Bentuk-bentuknya di dalam Alquran berupa (بر) yakni hanya terdapat di QS. Maryam ayat 14 dan (بررة) di QS. 'Abasa ayat 16.

Ma'rûfun (معروف)

Kata ini di dalam Alquran tidak ada bentuk lainnya kecuali hanya satu yaitu bentuk muannats nya (معروفة) yang yang terdapat di satu ayat yakni QS. An-Nûr ayat 54 (طاعة sعروفة) dan artinya pun berbeda sendiri, yakni menggunakan arti asalnya; yang dikenal, jadi maksud ayat itu 'ketaatan yang dikenal'. Selebihnya kata ma'rûf lebih dilekatkan pada makna cara yaitu cara yang baik atau selalu dilekatkan dengan kata (قول). 


\section{Bentuk-Bentuk Kata (خير) Dalam Alquran}

Kata merupakan isim mashdar yang terbentuk dari kata kerja (خير) خار , memiliki arti 'menjadi baik' ${ }^{14}$. Di dalam Alquran ayat-ayat yang terdapat kata (خير) ini ditemukan sebanyak 177 ayat ${ }^{15}$. Adapun jika ditinjau dari bilangannya, ayat-ayat yang mengandung isim jamak dari kata ini di dalam Alquran sebanyak dua belas ayat ${ }^{16}$. Ada pula beberapa kata kerja di dalam ayat Alquran yang berasal dari akar kata (خير) ini sebanyak enam ayat. ${ }^{17}$

\section{Dalam Bentuk Mufrad}

Ditinjau dari jenisnya bentuk mufrad, kata (خير) ada yang mudzakkar dan ada pula yang muannats. Bentuk muannats kata ini adalah (خيرة) , sementara bentuk mudzakkarnya adalah (خير) itu sendiri. Terdapat perbedaan antara kata (خير) dengan kata (خيرة) dalam penggunaannya. Kata (خير) biasanya digunakan secara umum. Di antaranya digunakan sebagai tafdhîl ${ }^{18}$, digunakan untuk menyifati, bermakna kebaikan itu sendiri, dan lain sebagainya. Sementara kata (خيرة) khusus digunakan untuk mewakili makna nomina dari kata kebaikan saja dan amal kebaikan atau kebajikan. ${ }^{19}$

Namun di dalam Alquran, tidak ditemukan samasekali kata (خيرة). Katakata yang bermakna kebaikan seluruhnya menggunakan kata (خير) atau kata (خيرة) tapi dalam bentuk jamak muannats sâlim, yakni (خير) (خير) (خير) (خير) itu sendiri memiliki banyak makna di dalam Alquran.

\section{Dalam Bentuk Jamak}

Bentuk jamak yang pertama adalah (الأخيار) yang biasanya menunjuk pada orang. Kata jamak ini tersebut di dalam Alquran pada dua ayat, yakni

${ }^{14}$ Mahmud Yunus, Kamus Arab - Indonesia, (Jakarta: Hidakarya Agung, 1989) h. 123

${ }^{15}$ Muhammad Fuad Abdul Bâqi, al-Mu'jam al-Mufahras Li al-Fâz̆h al-Qurân al-Karîm, (Beirut: Dâr al-Fikr, 1987) h. 249-251

16 Ibid. h. 251

${ }^{17}$ Faidhullah al-Husni al Maqdisi, Fath al-Rabmân, (Beirut: Dar al Kutub al Ilmiyyah, 2005) h. 142

${ }^{18}$ Musthafa al-Ghalayini, Jâmi' al-Durûs al-'Arabiyyah, (Kairo: Maktabah al-Syurûq alDauliyyah, 2008) h. 171

${ }^{19}$ Kamus al-'Ashry

${ }^{20}$ Muhammad Fuad Abdul Bâqi, al-Mu'jam al-Mufahras Li al-Fâz̆h al-Qurân al-Karîm, (Beirut: Dâr al-Fikr, 1987) h. 249-251 


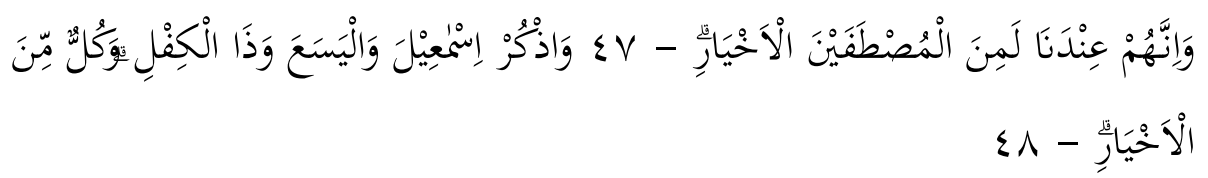

Dan sungguh, di sisi Kami mereka termasuk orang-orang pilihan yang paling baik. Dan ingatlah Ismail, Ilyasa' dan Zulkifli. Semuanya termasuk orang-orang yang paling baik. (Qs. Shâd ayat 47-48)

Pada ayat yang lain terdapat pula bentuk jamak (الخير ات) yang merupakan bentuk jamak muannats sâlim dari isim mufrad (خيرة). Sekali pun telah disampaikan di atas bahwa dalam bentuk mufradnya yakni (خيرة) itu sendiri tidak ditemukan di dalam Alquran. Adapun ayat-ayat yang dimaksud adalah sebagaimana berikut, QS. Al-Baqarah ayat 148, QS. Al-Imrân ayat 114, Qs. Al-Maidah ayat 48, Qs. AlAnbiyâ ayat 73, Qs. Al-Anbiyâ ayat 90, Qs. At-Taubah ayat 88, Qs. AlMukminûn ayat 56, Qs. Al-Mukminûn ayat 61, Qs. Fâthir ayat 32, Qs. ArRahmân ayat 70 .

Ditinjau dari ayat-ayat tersebut, baik yang mengandung kata (الأخيار) maupun (الخير ات), diketahui bahwa kedua kata jamak tersebut penggunaannya di dalam kalimat sama dengan penggunaan isim mufrad-nya di dalam kalimat. (الأخيار) yang merupakan bentuk jamak taktsîr dari isim mufrad (خير) memiliki penggunaannya dalam kalimat juga secara umum. Dalam QS. Shaad ayat 47 dan 48, ia berfungsi sebagai tafdhîl, yaitu bermakna banyak kebaikan padanya sehingga menjadi paling baik (al-katsîr al-khair) ${ }^{21}$. Demikian halnya dengan kata (الخير ات), ia memilki fungsi yang sama dengan isim mufrad-nya yakni terbatas pada makna kebaikan-kebaikan atau amal kebaikan.

\section{Dalam Bentuk Kata Kerja}

Di dalam Alquran terdapat ayat-ayat yang mengandung kata kerja yang akar katanya sama berasal dari kata (خير), yakni ayat-ayat sebagai berikut,

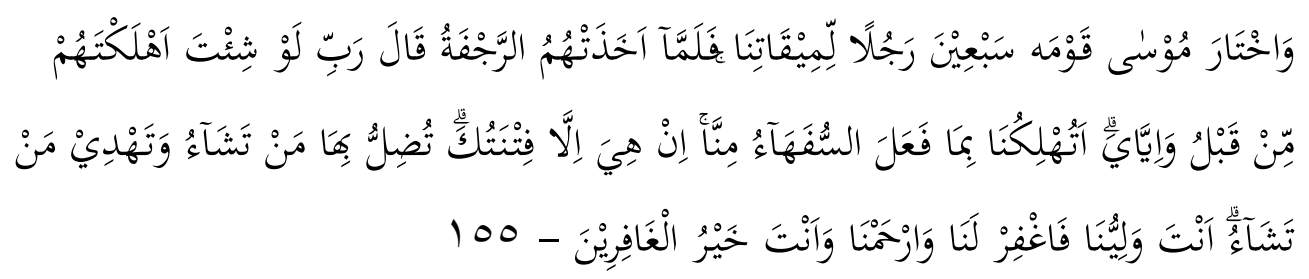

Dan Musa memilih tujuh puluh orang dari kaumnya untuke (memohon tobat kepada Kami) pada waktu yang telah Kami tentukan. Ketika mereka ditimpa gempa bumi, Musa berkata, "Ya Tubanku, jika Engkau kehendaki, tentulah Engkau binasakan mereka dan aku

${ }^{21}$ Louis Ma’luf, Al-Munjid Fi al-Lughah, (Beirut: Dar al Masyruq, 1977) h. 201 
sebelum ini. Apakah Engkau akan membinasakan kami karena perbuatan orang-orang yang kurang berakal di antara kami? Itu hanyalah cobaan dari-Mu, Engkau sesatkan dengan cobaan itu siapa yang Engkau kehendaki dan Engkau beri petunjuk kepada siapa yang Engkau kehendaki. Engkaulah pemimpin kami, maka ampunilah kami dan berilah kami rahmat. Engkaulah pemberi ampun yang terbaik." (Qs. Al A'râf ayat 155)

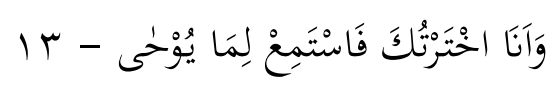

Dan Aku telah memilih engkau, maka dengarkanlah apa yang akan diwahyukan (kepadamu). (Qs. Thaha ayat 13)

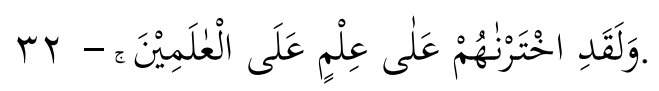

Dan sungguh, Kami pilih mereka (Bani Israil) dengan ilmu (Kami) di atas semua bangsa (pada masa itu). (Qs. Al-Dukhân ayat 32

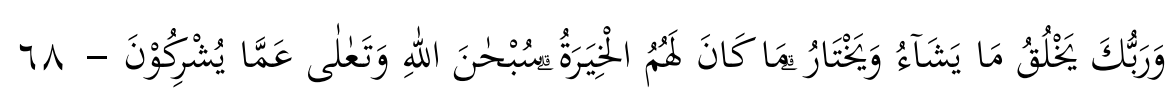

Dan Tubanmu menciptakan dan memilih apa yang Dia kehendaki. Bagi mereka (manusia) tidak ada pilihan. Mahasuci Allah dan Mahatinggi Dia dari apa yang mereka persekutukan. (Qs. Al-Qashash ayat 68)

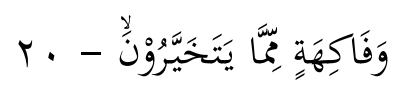

Dan buab-buahan apa pun yang mereka pilih, (Qs. Al Wâqi'ah ayat 20)

Baik kata kerja اختار pada QS. Al A’râf ayat 155, اختر pada QS. Thaha ayat 11 dan al-Dukhân ayat 32, يختار pada QS. Al Qashash ayat 68, dan (يتخيرون) pada Qs. Al Wâqiah ayat 20 semuanya itu berasal dari kata (خير (خير). ${ }^{22}$ Walaupun berbeda-beda dalam bentuk atau wazan, semua kata itu memiliki pengertian yang sama yakni memilih. Makna memilih pada setiap kata kerja itu juga memiliki ciri khas, yakni memilih yang mengandung unsur kebaikan atau memilih dengan mempertimbangkan kebaikan.

\section{Diawali Dengan Alif-Lam (ال)}

Di dalam kaidah bahasa Arab isim yang diawali dengan alif-lam (ال) merupakan salah satu ciri dari isim ma'rifah selain dari ciri-ciri lainnya seperti isim dhamir, isim 'alam, isim maushul, isim isyarah, isim yang di-mudhaf-kan kepada isim

${ }^{22}$ Abi al-Husain bin Fâris bin Zakariyya, al-Maqayis Fi al-Lughah, (Beirut: Dâr al-Fikr, 
ma'rifah, dan munada maqshudah ${ }^{23}$. Adapun di dalam kaidah tafsir isim yang dita'rif dengan alif-lam (ال) berfungsi untuk menunjukkan sesuatu yang sudah diketahui karena telah disebutkan (ma'bûd zilkr), untuk menunjukkan sesuatu yang sudah diketahui bagi pendengar, menunjukkan sesuatu yang sudah diketahui karena ia hadir pada saat itu, untuk mencakup semua satuannya (istighrâq al-afrad), untuk menghabiskan segala karakteristik jenis, dan untuk menerangkan esensi, hakikat, dan jenis. ${ }^{24}$

Terkait dengan pembahasan ini, kata (خير) yang diawali dengan alif-lam (ال(خير) ditemukan sebanyak 13 ayat. Yakni QS. Al-Imrân ayat 26, QS. AlImran ayat 104, QS. Al-Ma'ârij ayat 21, QS. Al-A'râf ayat 188, QS. Yûnus ayat 11, QS. Al-Isra ayat 11, Qs. Al-Anbiyâ ayat 35, QS. Al-Ahzab ayat 19, QS. Shâd ayat 32, QS. Fushilat ayat 49, QS. Qaf ayat 25, QS. Al -'Adiyat ayat 8, dan QS. Al-Hâj ayat $77 .^{25}$

\section{Bentuk (خير) Preferensi}

Di dalam Alquran kecenderungan Allah untuk memilih sesuatu yang dianggap lebih baik daripada yang lainnya terdapat pada ayat-ayat yang mengandung kata (خير) di dalamnya. Namun, tidak semua kata (خير) di dalam Alquran adalah preferensi. Sebab kata (خير) itu sendiri memiliki beberapa arti pada ayat-ayat di dalam Alquran.

Terkait dengan bentuk-bentuk kata (خير) di dalam Alquran sebagaimana yang telah dijelaskan pada subbab sebelumnya, (خير) preferensi tidak memiliki bentuk lain selain bentuk (خير) itu sendiri. Dengan kata lain, (خير) preferensi tidak ditemukan dalam bentuk jamak ataupun dalam bentuk yang diawali dengan ta'rif alif-lam. Melainkan kata (خير) yang memiliki pengertian preferensi seluruhnya berbentuk mufrad, berbentuk nakirah, dan selalu berkedudukan sebagai khabar dalam kalimat.

Cukup banyak di dalam Alquran ayat-ayat yang terdapat (خير) preferensi di dalamnya. Ayat-ayat yang dimaksud anatara lain QS. Al-Baqarah ayat 54, QS. Al-Baqarah ayat 61, QS. Al-Baqarah ayat 184, QS. Al-Baqarah ayat 216, QS. AlBaqarah ayat 263, QS. Al-Baqarah ayat 271, QS. Al-Baqarah ayat 280, QS. AnNisâ ayat 25, QS. Al-A'râf ayat 26, QS. Al-A'râf ayat 85, QS. Al-Anfal ayat 19, QS. At-Taubah ayat 3, QS. At-Taubah ayat 41, QS. Yûsuf ayat 57, QS. An-Nahl

${ }^{23}$ Akhmad Munawari, Belajar Cepat Tata Bahasa Arab, (Yogyakarta: Nurma Media Idea, 2007) h. x

${ }^{24}$ Mannâ’ Khalîl al-Qattân, Mabahits fi Ulum al-Qur'an, (Mansyurat al-Asr al-Hadis, 1973)

\footnotetext{
2005) h. 144

${ }^{25}$ Faidhullah al-Husni al-Maqdisi, Fath al-Rahmân, (Beirut: Dâr al-Kutub al-'Ilmiyyah,
} 
ayat 95, QS. Al-Kahfi ayat 46, QS. Al-Hâj ayat 30, QS. Al-Mukminûn ayat 72, QS. An-Nûr ayat 27, QS. Al-Qashash ayat 80, QS. Al-Ankabut ayat 16, QS. Ash-Shafat ayat 62, QS. Muhammad ayat 21, QS. Al-Mujâdilah ayat 12, QS. Ash-Shaf ayat 11, QS. Al-A'lâ ayat 17, QS. Ad-Dhuhâ ayat 4, QS. Al-Qadr ayat 3.

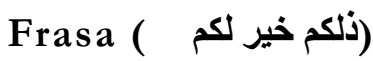

Ditemukan beberapa frasa di dalam Alquran yang diulang-ulang dalam beberapa ayat yang berbeda. Contohnya frasa (فبأي آلاء ربكما تكنبان) yang diulang-

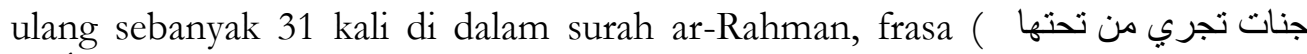
(الأنهار yang diulang di dalam beberapa ayat yang berbeda, dan beberapa frasa lainnya. Demikian halnya dengan frasa (ذلكم خير لكم) yang diulang-ulang sebanyak tujuh kali di dalam al Quran.

Sebagaimana yang telah dikemukakan sebelumnya bahwa tidak semua ayat yang terdapat kata (خير) di dalamnya mengandung preferensi, sebab kata (خير) tidak hanya memiliki satu arti melainkan banyak arti. Tapi beda halnya ketika kata (خير) berdampingan dengan kata lain membentuk sebuah frasa (خلكم) (خير لكم ( maka seluruh ayat yang terdapat frasa tersebut di dalamnya mengandung preferensi.

Sebagai contoh; QS. Al-Jumu'ah ayat 9,

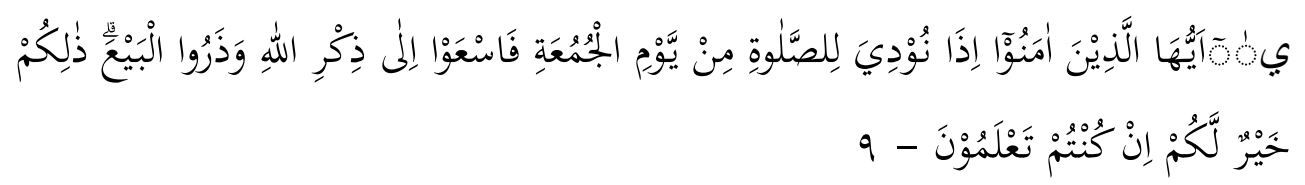

Wahai orang-orang yang beriman! Apabila telah diseru untuk melaksanakan salat pada hari Jum'at, maka segeralah kamu mengingat Allah dan tinggalkanlah jual beli. Yang demikian itu lebib baik bagimu jika kamu mengetahui.

Ayat ini merupakan perintah kepada umat Islam untuk menunaikan shalat Jumat. Itu artinya shalat jumat adalah sebuah kebaikan. Di sisi lain, banyak ayat yang memperbolehkan jual beli. Namun, di saat kedua aktifitas itu dilakukan pada waktu yang bersamaan, Allah menggunakan preferensi-Nya untuk memberi petunjuk kepada manusia. Allah memilih shalat Jumat untuk diutamakan daripada jual beli.

Adapun ayat-ayat yang mengandung frasa ( ذلكم خير لكم ini terdapat di dalam Alquran sebanyak tujuh kali, yakni pada masing-masing ayat sebagai berikut; QS. Al-Baqarah ayat 54, QS. Al-A'râf ayat 75, QS. At-Taubah ayat 41, 
QS. An-Nûr ayat 28, QS. Al-Ankabut ayat 16, QS. Ash-Shaf ayat 11, dan QS. Al-Jumuah ayat 9 .

\section{Kesimpulan}

Konsep preferensi di dalam Alquran terkandung pada ayat-ayat yang terdapat kata (خير) di dalamnya. Namun, tidak semua kata (خير) yang ada di dalam suatu ayat memberikan makna preferensi. Sebab, kata (خير) di dalam Alquran memiliki beberapa makna. Kata (خير) yang bermakna preferensi adalah salah satu di antaranya.

Adapun yang menjadi ciri khusus kata (خير) yang memiliki pengertian sebagai preferensi adalah dapat dilihat dari bentuknya. Yaitu (خير) preferensi semuanya berbentuk mufrad, berbentuk nâkirah, dan selalu berkedudukan sebagai khabar dalam kalimat. Dapat pula dilihat dari makna ayat secara utuh. Biasanya kata (خير) yang bermakna preferensi berfungsi sebagai tafdhîl sehingga berarti 'lebih baik'.

Ketika kata (خير) berangkai dengan beberapa kata lain membentuk sebuah frasa (ذلكم خير لكم), maka semua ayat yang terdapat frasa itu di dalamnya mengandung konsep preferensi. Frasa yang mengandung konsep preferensi ini memiliki faedah sebagai berikut:

Pertama, Memberi penekanan atau penegasan pada perintah yang terkandung di dalam ayat. Di dalam ayat, frasa ini selalu didahului oleh sebuah perintah. Baik itu perintah untuk mengerjakan suatu amal perbuatan atau perintah untuk melarang suatu amal perbuatan. Kemudian frasa ini melakukan keberpihakan kepada perintah itu dengan mengatakan, 'jika perintah itu ditaati, maka hal itu lebih baik bagimu.'

Kedua, sebagai sugesti kepada manusia untuk menjatuhkan pilihan kepada apa yang Allah perintahkan di dalam ayat itu. Mengarahkan manusia untuk cenderung untuk mentaati apa yang diperintahkan.

Ketiga, sebagai metode komunikasi yang baik. Setelah memberi perintah, Allah mengajak manusia melalui frasa ini. Metode ini baik jika dipakai di dalam dunia dakwah, kepemimpinan, manajemen, dan sebagainya. Beberapa orang tidak senang jika hanya menerima kalimat perintah terus-menerus. Namun, ia tidak merasa terganggu jika diajak. Padahal apa yang diperintahkan dengan apa yang diajak itu adalah suatu hal yang sama. Demikian salah satu tabiat yang dimiliki sebagian orang. Terkait dengan hal itu, Alquran mencontohkan cara yang terbaik bagaimana menghadapi orang-orang yang memiliki tabiat seperti itu. Salah satunya adalah dengan kalimat preferensi seperti ini. 


\section{Bibliografi}

Bâqi, Muhammad Fuad Abdul, al-Mu'jam al-Mufahras Li al-Fâ̧̋h al-Qurân alKarim, (Beirut: Dâr al-Fikr, 1987)

Cambridge University Team, Cambridge Advanced Learner's Dictionary, (Singapore: Green Giant Press, 2008)

Echols, John M. dan Hassan Shadily, Kamus Inggris-Indonesia, Jakarta: Gramedia, 2003)

Enoh, "Konsep Baik (Kebaikan) dan Buruk (Keburukan) dalam Alquran," Mimbar Jurnal Ilmu Sosial dan Pembangunan Vol. 23 No. 1 Tahun 2007.

Lihat

https://ejournal.unisba.ac.id/index.php/mimbar/article/view/232

Faiz, Ahmad. Analisis Perbandingan Kata Khair, Hasan, dan Thayyib dalam Al-Quran Berdasarkan Tafsir Ibnu Katsir, Jalalain, Departemen Agama dan Baghawy. (Skripsi, Jurusan Sastra Arab, Fakultas Sastra, Universitas Negeri Malang, 2016).

Al-Ghalayini, Musthafa, Jâmi' al-Durûs al-'Arabiyyah, (Kairo: Maktabah al-Syurûq al-Dauliyyah, 2008)

Gulen, Muhammad Fethullah, Islam, Penerjemah Fauzi A. Bahreisy (Jakarta: Republika Penerbit, 2011)

Al-Husain, Abi bin Fâris bin Zakariyya, al-Maqayis Fi al-Lughah, (Beirut: Dâr alFikr, 1994)

Al-Maqdisi, Faidhullah al-Husni, Fath al-Rabmân, (Beirut: Dar al Kutub al Ilmiyyah, 2005)

Ma'luf, Louis, Al-Munjid Fi al-Lughah, (Beirut: Dar al Masyruq, 1977)

Munawari, Akhmad, Belajar Cepat Tata Bahasa Arab, (Yogyakarta: Nurma Media Idea, 2007)

Al-Qattan, Manna' Khalil, Mababits fi Ulum al-Qur'an, (Mansyurat al-Asr alHaidis, 1973)

al-Qurthubi, Abi Abdillah Muhammad bin Ahmad al-Anshâri, al-Jâmi' li Ahkeâm al-Qurân, Juz. 1

Shihab, M. Quraish, Tafsir al-Misbah. (Jakarta : Lentera hati, 2000)

al-Suyuthi, Jalaluddin Abdurrahman, al-Itqân fì Ulùm Alquran, (Beirut: alMaktabah al-'Ashriyyah, 1988) 
256 | AL QUDS : Jurnal Studi Alquran dan Hadis vol. 3, no 2, 2019

Al-Suyuthi, Jalaluddin Abdurrahman dan Jalaluddin al-Mahalli, Tafsîr al- Imâmain al-Jalalain, (Beirut: Dâr al-Ma'rifah)

Tim Pusat Bahasa, Kamus Besar Bahasa Indonesia, Jakarta: Gramedia Pustaka Utama, 2008)

Yunus, Mahmud, Kamus Arab - Indonesia, (Jakarta: Hidakarya Agung, 1989)

Yulia Rahmi, Makna Khair dalam Alquran, (Skripsi, Fakultas Ushuluddin dan Pemikiran Islam UIN Sunan Kalijaga Yogyakarta, 2014) 